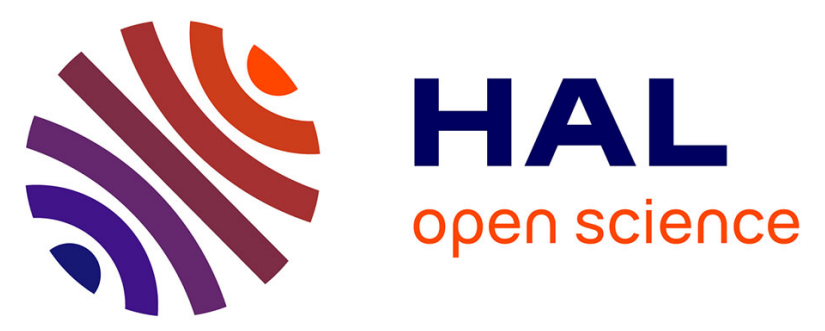

\title{
Accumulation and changes in molecular size distribution of polymeric proteins in developing grains of hexaploid wheats: role of the desiccation phase
}

J. L Carceller, Thierry Aussenac

\section{- To cite this version:}

J. L Carceller, Thierry Aussenac. Accumulation and changes in molecular size distribution of polymeric proteins in developing grains of hexaploid wheats: role of the desiccation phase. Functional Plant Biology, 1999, 26 (4), pp.301. 10.1071/PP99010 . hal-03159927

\section{HAL Id: hal-03159927 \\ https://hal.science/hal-03159927}

Submitted on 4 Mar 2021

HAL is a multi-disciplinary open access archive for the deposit and dissemination of scientific research documents, whether they are published or not. The documents may come from teaching and research institutions in France or abroad, or from public or private research centers.
L'archive ouverte pluridisciplinaire HAL, est destinée au dépôt et à la diffusion de documents scientifiques de niveau recherche, publiés ou non, émanant des établissements d'enseignement et de recherche français ou étrangers, des laboratoires publics ou privés. 


\title{
Accumulation and changes in molecular size distribution of polymeric proteins in developing grains of hexaploid wheats: role of the desiccation phase
}

\author{
J.L. Carceller and T. Aussenac ${ }^{A}$
}

Laboratoire d'Agrophysiologie, Ecole Supérieure d'Agriculture de Purpan 75, voie du Toec, 31076 Toulouse cedex 03, France

${ }^{A}$ Corresponding author, email : Aussenac@esa-purpan.fr 


\section{Abstract}

Two varieties of wheat differing in high-molecular weight glutenin subunit composition (Soissons, 5+10, Glu-D1a allele; Thésée, 2+12, Glu-D1a allele) were examined to follow the accumulation of polymeric proteins and the changes in molecular size distribution of these proteins during grain filling. The accumulation behaviour of polymeric proteins was determined by size-exclusion-HPLC, multistacking SDS-PAGE and the constituent polypeptides (HMW and LMW glutenin subunits) by reversed-phase-HPLC.

For both cultivars, the accumulation of each class of protein was highly asynchronous, especially between the early deposition of SDS-soluble polymers and the late deposition of SDS-insoluble polymers, such that the average molecular size of polymeric protein increased in the period from 30 to 45 days after anthesis in natural conditions.

By applying premature grain desiccations during the cell enlargement phase, it was demonstrated that the SDS-insoluble polymers formation was closely related with the process of water loss from the grain. Moreover, the rapid accumulation of SDS-insoluble polymers coincided with a rapid decrease in mass of both SDSsoluble polymers and monomers, suggesting an aggregative mechanism. Over the same period, the molecular size distribution of the polymers which can be used to differentiate the two genotypes studied, is highly correlated with the percentage of high-molecular weight glutenin subunits in glutenins present in kernels when desiccation occurred. The formation of SDS-insoluble fraction is discussed in connection with the specific contribution of high-molecular weight glutenin subunits to the formation of polymers (subunits linked by disulfide bonds).

\section{Introduction}


The storage proteins constitute about $85 \%$ of the endosperm proteins in wheat kernels and are traditionally classified into gliadins and glutenins. The gliadins, which impart extensibility and viscosity to the dough (Wall 1979), are monomeric proteins. The glutenins, which impart elasticity and strength to the dough (Wall 1979 ; Bietz and Huebner 1980) contain polymeric proteins built up from a number of subunits linked by disulfide bonds (Shewry and Tatham 1990).

Differences in breadmaking quality among flours are to a large extent determined by differences in the polymeric protein fractions. The total glutenin polymer quantity is known to be correlated with various technological parameters (Huebner and Wall 1976 ; Field et al. 1983 ; Dachkevitch and Autran 1989 ; Singh et al. 1990a, 1990b). Moreover, a certain amount of these polymers remain unextractable in various extracting systems (e.g. acetic acid solution or SDS phosphate buffer). Those unextractable polymeric proteins appear also to be correlated positively with the baking performance (Kurowska and Bushuk 1988 ; Gupta et al. 1993 ; Jia et al. 1995). Besides, Gupta et al. (1992) showed that the unextractable polymer quantity is more directly linked with certain technological parameters (especially those correlated with mixing) than the total glutenin quantity. The proportion of unextractable polymer fraction (Fi fraction) among the glutenin polymers appears likewise to be an important ratio for the technological response (Gupta et al. 1993, Jia et al. 1996).

Regarding the importance of the diverse polymer protein parameters (quantity and proportion) in breadmaking quality, it seems interesting to study the accumulation of those fractions in the kernel during grain filling. These observations would give us more information about the structure of these different polymers, which is still a matter for speculation. To our knowledge, only a few papers have reported 
information about the accumulation of those specific fractions during grain filling ( e.g. Bénétrix et al. 1994 ; Johansson et al. 1994 ; Gupta et al. 1996 ; Stone and Nicolas 1996).

Furthermore, no definitive conclusion appears to have been reached about the formation of the unextractable polymers even if some authors (Woodman and Engledow 1924 ; Stone and Nicolas 1996) found a partial correspondence between the formation of SDS insoluble polymers and the period of rapid loss of water (grain desiccation). For example, Stone and Nicolas (1996) reported a strong correlation $(r=0.91, \mathrm{P}<0.01)$ between the two.

In this study, we followed the accumulation of polymeric proteins and the changes in molecular size distribution of these protein fractions (SDS-soluble polymers and SDS-insoluble polymers) during grain filling through SE-HPLC analysis and SDSPAGE Multistacking under natural and premature desiccation.

The specific contribution of HMWgs, LMWgs and monomers to the polymeric status (SDS-insoluble polymers/total polymers) was monitored for the two genotypes Thésée and Soissons. 


\section{Material and methods}

Plant material

The two wheat cultivars used in this study were Soissons and Thésée possessing Glu-D1 subunits $5+10$ and $2+12$ respectively. These cultivars were grown at the experimental farm of ESAP Toulouse, France (1996-1997).

The experimental design was a randomised complete block with four replications (plots of $60 \mathrm{~m}^{2}$ ). At the first day of anthesis, each spike was tagged and dated. Subsequently, 30 spikes per replication were collected at 2 day intervals from the 5th DAA up to the 53rd DAA. The freshs weight of 30 grains were taken and then grains were oven dried at $80^{\circ} \mathrm{C}$ to a constant weight after which the dry weight was taken. The difference between these two weights gave the water content in mg.1000 kernels ${ }^{-1}$ at each time. Seed dry weight data was fitted to a biphasic linear regression of intersecting segments (Green et al. 1985). Details of the method followed are as described earlier by Chanda and Singh (1996).

For all the biochemical determinations, the fresh grains were freeze-dried and finally ground $(200 \mu \mathrm{m})$ in a Janke $\mathrm{A} 10$ grinder.

For applying artificial desiccation of the kernels, four samples $(20,24,28$ and 32 DAA) were used. The fresh grains (30 spikes) were oven-dried at $30^{\circ} \mathrm{C}(\mathrm{a}$ temperature normally recorded during the grain dessication phase) for 3 days until the grains reached a constant humidity. The same protocol as before was applied to the desiccated grains (freeze-dried and ground). 
Quantification and measurement of relative size distribution of polymeric proteins by SE-HPLC

Extraction of total proteins and separation by SE-HPLC was carried out as described by Gupta et al. (1993), with the following modifications.

The total polymeric protein was separated into two size fractions based on its extractability in $2 \%(\mathrm{w} / \mathrm{v})$ SDS-phosphate buffer (without sonication), i.e. extractable (Fs) and unextractable (Fi) fractions.

Flour $(0.01 \mathrm{~g})$ was suspended in $1 \mathrm{~mL}$ of $0.1 \mathrm{M}$ sodium phosphate buffer $(\mathrm{pH} 6.9)$ containing $2 \%(\mathrm{w} / \mathrm{v})$ SDS and stirred for $2 \mathrm{~h}$ at $60{ }^{\circ} \mathrm{C}$. These extractions were followed by centrifugation during $30 \mathrm{~min}$ at $12500 \times \mathrm{g}$ at $20^{\circ} \mathrm{C}$ to obtain a supernatant (Fs or extractable protein).

The unextractable fraction (Fi) was then sonicated for $15 \mathrm{~s}$ at $50 \%$ power (output $25 \mathrm{~W}, 23 \mathrm{kHz})$ in $2 \%$ SDS-phosphate buffer $(1 \mathrm{~mL})$ using a stepped mictotip probe ( $3 \mathrm{~mm}$ diameter) to solubilize the remaining protein (unextractable proteins). Both extracts were filtered through $0.45 \mu \mathrm{m}$ filters and then injected $(20 \mu \mathrm{L})$ onto a TSK G 4000 SW (TOSOHAAS, Germany) size exclusion analytical column (7.5 x 300 $\mathrm{mm}, 45 \mathrm{~nm})$.

The HPLC apparatus was a Spectra SYSTEM LC (Thermo Separation Products S.A., Les Ulis, France) consisting of an online degasser (model SCM 400), isocratic pump (model P4000), variable auto-injector (model AS3000) and variable wavelength detector (model UV 2000). Sodium phosphate buffer $(0.1 \mathrm{M}, \mathrm{pH} 6.9)$ containing $0.1 \%(\mathrm{w} / \mathrm{v})$ SDS was used as eluent with a flow rate of $0.7 \mathrm{~mL} / \mathrm{min}$. During the fractionation, the column was thermostated at $25^{\circ} \mathrm{C}$.

For the extractable fraction, the elution profile was divided into two main peaks corresponding to polymeric protein and monomers respectively according to 
Gupta et al. (1993). Since the polymeric protein fraction contained mainly glutenin (Jia et al. 1995), it was referred to previously as glutenin and the monomer fraction as majority gliadins. The percentage of unextractable polymeric protein in total polymeric protein were calculated as follows :

[peak 1 area (extractable) / (peak 1 area (extractable) + peak 1 area (unextractable))] $\times 100$ The quantities of the different fractions (polymeric extractable proteins, polymeric unextractable proteins and monomers) were estimated by the absolute area of the fraction. There is indeed a very strong linear relationship between the amount of total protein in flour estimated by the Dumas method (AOAC 7.024) and the total area of the chromatogram for each flour sample $\left(r^{2}=0,9 ; n=165\right)$ (Jia et al. 1996).

\section{Multistacking gel electrophoresis}

The multistacking SDS-PAGE was performed according to Khan and Huckle (1992). In this procedure, five stacking gels at $\mathrm{pH} 6.90$ with various acrylamide concentrations $(4,6,8,10$ and $12 \% \mathrm{w} / \mathrm{v})$ on top and $14 \%$ separating gel were used to separate the different glutenin polymers at the various origins of the stacking gels. A gel thickness of $3 \mathrm{~mm}$ was used for analytical multistacking SDSPAGE. For all developmental stages, one kernel was pulverised and proteins were extracted by $2 \%(w / v)$ SDS-phosphate buffer as described in the previous section.

\section{Quantification of glutenin subunits by RP-HPLC}

Ground kernel samples $(0.5 \mathrm{~g})$ were stirred for $1 \mathrm{~h}$ at room temperature $\left(25^{\circ} \mathrm{C}\right)$ with $2.25 \mathrm{~mL}$ of $0.080 \mathrm{M}$ Tris- $\mathrm{HCl}$ buffer $(\mathrm{pH} 7.5)$ containing $50 \%(\mathrm{v} / \mathrm{v}) 1$-propanol. Extraction was followed by centrifugation at $15900 \times g$ for $30 \mathrm{~min}$ at $15^{\circ} \mathrm{C}$. Glutenins soluble in $50 \%$ 1-propanol were precipitated by the addition of $1.5 \mathrm{~mL}$ 
of 1-propanol to bring the 1-propanol concentration of the supernatant to $70 \%$ (v/v) (Fu and Sapirstein 1996). The mixture was agitated and allowed to stand at room temperature for $1 \mathrm{~h}$. After centrifugation $\left(26000 \times \mathrm{g}, 15 \mathrm{~min}\right.$ at $\left.15^{\circ} \mathrm{C}\right)$, the supernatant (mainly monomeric proteins) was eliminated. The residue (polymeric proteins) was then extracted with $2.25 \mathrm{~mL}$ of the $0.080 \mathrm{M}$ Tris- $\mathrm{HCl}$ buffer $(\mathrm{pH} 7.5)$ containing $50 \%(\mathrm{v} / \mathrm{v})$ 1-propanol and $1 \%(\mathrm{w} / \mathrm{v})$ DTT by continual stirring for $1 \mathrm{~h}$ at $60^{\circ} \mathrm{C}$. The supernatant obtained after a centrifugation at $15,900 \times \mathrm{g}$ for $30 \mathrm{~min}$ at $15^{\circ} \mathrm{C}$ was filtered through a $0.45 \mu \mathrm{m}$ filter. An aliquot $(600 \mu \mathrm{L})$ was then alkylated with $40 \mu \mathrm{L}$ of $70 \%(\mathrm{v} / \mathrm{v})$ 4-vinylpyridine in $50 \%(\mathrm{v} / \mathrm{v})$ 1-propanol buffered with 0.080 M Tris- $\mathrm{HCl}(\mathrm{pH} 7.5)$ at $60^{\circ} \mathrm{C}$ for 20 min just prior to RP-HPLC analysis.

Samples were analysed using a PC 1000/Spectranet data and chromatography control station (Spectra Physics analytical software, San Jose, CA, USA) incorporating a solvent degasser, solvent delivery system, auto-sampler, and heated column compartment maintained at $50^{\circ} \mathrm{C}$ for analyses. A Zorbax $300 \mathrm{SB}$ C8 (Supelco Inc., Bellefont, PA, USA) column (30 nm pore size, $5 \mu \mathrm{m}$ particle size, $15 \mathrm{~cm} \times 4.6 \mathrm{~mm}$ id) was used in conjunction with a Zorbax 300 SB-C8 cartridge guard column (1.25 $\mathrm{cm} \times 4.0 \mathrm{~mm}$ i.d. $)$.

Solvents for RP-HPLC were : $A$, deionized water filtered $(0.1 \mu \mathrm{m})$; and $B$, acetonitrile (ACN, HPLC grade, $0.45 \mu \mathrm{m}$ filtered). Both solvents contained $0.1 \%$ (v/v) trifluoroacetic acid (HPLC Grade, Sigma). Solvents flow rate was maintained at $1.0 \mathrm{~mL} / \mathrm{min}$. After an initial $3 \mathrm{~min}$ isocratic condition at $23 \%$ solvent $\mathrm{B}$, reduced and alkylated glutenin subunits were eluted in a 82 min linear gradient from 23 to $44 \%$ solvent $B$. The column was equilibrated at $23 \%$ solvent $B$ for 8 min between runs. The column effluent was monitored at $214 \mathrm{~nm}$ using a Spectra 2000 
detector. Injection volumes were $30 \mu \mathrm{L}$ in conjunction with a multiple $5 \mu$ linjection technique (Marchylo et al. 1989).

\section{Results}

Individual kernel mass and grain water content

Grain dry weight data was fitted to biphasic linear regression analysis. For the two varieties, an initial lag, with low growth rate, and later, a linear dry matter accumulation phase were discernable (Fig. 1a). The initial lag phase ranged from 10-15 DAA, while the linear dry matter accumulation phase ranged from 15 to 40 DAA. Then the dry matter declined. The rate and duration of the dry matter accumulation was very similar for each variety. Both Soissons and Thésée accumulated dry matter in the period 15-43 DAA, at the rate of $1.2 \mathrm{mg} \mathrm{day}^{-1}$. Changes in water content of the kernels of the two varieties are given in Fig. $1 b$. The lowest water content was at 5 DAA which gradually increased and reached a maximum level around 21 DAA. After 21 DAA, the water content almost remained constant up to 31-33 DAA and declined thereafter. Studies of grain growth and water content in the present investigation showed that dry weight, for the two varieties, recorded an initial lag phase (10-15 DAA), followed by a linear dry matter accumulation phase and the grains attained maximum dry weight around 43 DAA. On the other hand, water content kernel ${ }^{-1}$ recorded a shorter lag phase $(5-10$ DAA) which was followed by a rapid uptake of water and the maximum water content kernel $^{-1}$ was recorded around 21 DAA, much before the attainment of maximum dry weight (Fig. 1b). Similar patterns of dry matter accumulation and water uptake have been reported earlier (Dale and Housley 1986 ; MartinezCarrasco et al. 1988). In the present work, from biphasic regression analysis and 
data of water content, wheat grain development can be divided in three phases (P1) cell division, (P2) cell enlargement and dry matter accumulation, and (P3) grain dehydration or maturation (Wang and Gifford 1995).

\section{Accumulation of polymeric and monomeric proteins}

Figs $2 a$ and $2 b$ provide an overall picture of the relative contribution of each protein fraction to the total grain protein. The SE-HPLC measurements of the three main classes of proteins indicated that the absolute amount of albumins/globulins (peak 3) increased only initially (up to 21-22 DAA) and then remained constant. On the other hand, absolute amounts of gliadins (peak 2) and SDS soluble polymeric proteins (peak 1) increased with grain development until 31 and 40 DAA respectively. The composition of protein thus changes during grain development, containing the highest percentage of albumins/globulins, gliadins and polymers during the early (7-21 DAA), mid (22-31 DAA) and late (around 40 DAA) developmental stages, respectively. This is consistent with the results based on sequential solubility criteria (Dell'Aquilla et al. 1983). Polymers were almost entirely (at least 95\%) composed of SDS-soluble polymers until 31 DAA. Thereafter significant reductions in the quantity of gliadins and SDS soluble polymers occurred between 31 DAA and maturity. SDS insoluble polymers did not contribute significantly to protein mass until 31 DAA, but after this, its mass increased steadily.

The polymer/monomer ratio evolved at the time as the grains developed (Fig. 3a). This ratio remained constant during the cellular division and enlargement stages, increased significantly during the grain dehydration phase (from 31 to 32 DAA) to 
reach its maximum at 40 DAA. In a few days, we observed a doubling of the ratio for the two cultivars Soissons and Thésée. As we can see in Fig. 3b, the increase of the ratio is due to the mobilization of a part of the monomeric and/ or oligomeric forms into the polymeric forms. This phenomenon can be observed in the same way for the two cultivars studied Soissons and Thésée.

\section{Changes in molecular size distribution of polymeric proteins}

Accumulation of polymeric proteins began early in the grains (from 7 DAA) and continued until 40 DAA. During the cellular division and enlargement phases, the accumulation of these polymeric forms is linear (up to 31 DAA). But this accumulation amplified during the first days of grain dehydration (Fig. 4a). This amplification of the accumulation pattern results in the doubling of the polymeric content. The behaviour of the two genotypes is very close : it seems difficult to show significant differences in the accumulation patterns. Moreover, the polymeric contents of Soissons and Thésée are identical at maturity.

The SDS extractability criterion was used to estimate the molecular size distribution of polymers, where extractable polymers were considered to have a smaller average size than the unextractable polymers (Gupta et al. 1993).

The SDS-soluble polymers accumulated regularly till 35 DAA. Beyond this date, we noticed a significant decrease of this soluble polymeric fraction (Fig. $4 b$ ). The SDS-insoluble polymers appeared at the end of the cell enlargement stage (31 DAA) and accumulated swiftly during the dehydration phase of the grains (until 40 DAA).

During the cell division phase, the behaviour of the two genotypes was very close. On the contrary, during the cellular enlargement and the grain dehydration stage, 
the behaviours diverged. Actually, Thésée accumulated more SDS-soluble polymers than Soissons. At maturity, the quantity of SDS-insoluble polymers of Soissons is twice the quantity of Thésée. Then, even if the accumulation period of the polymeric fraction during the grain development for the two genotypes Soissons and Thésée seems to be identical, the polymerisation level reached at maturity is determined by the nature of the genotype. The average molecular mass of the Soissons polymers (glu $D 5+10$ ) is more important than that of Thésée polymers (glu D 2+12) at maturity (Fig. 4c).

At the same time, the procedure of multistacking SDS-gel electrophoresis was used to follow the rate of polymerisation of glutenin subunits during grain filling. This procedure involves electrophoresis of the different extracts in a multilayer-gel system. As pointed by Khan and Huckle (1992), at each interphase, labelled 4 to $14 \%$ in Fig. 5 , there is some protein material that did not enter the corresponding gel. This protein material is glutenin polymer. Therefore, the protein material at each interphase has a different size. The larger glutenin polymers remained at the origin of the largest gel pore $(4 \%)$ while the smallest polymers migrated to the interphase of the gel with the smallest pore size, the $14 \%$ resolving gel.

SDS-PAGE multistacking patterns of SDS-extracts of total protein revealed that, during the accumulation of polymeric proteins, a continuous polymerisation phenomenon can be observed, resulting in polydisperse fractions of glutenin of different sizes. The amount of material remaining at the different gel interphases increased from 7 DAA to 35 DAA (Figs. $5 a$ and $5 b$ ). This phenomenon can be observed in the same way for the two cultivars studied, Soissons and Thésée. 
RP-HPLC patterns of propanol-DTT extracts of total proteins revealed that the HMW (A subunits) and LMW glutenin subunits $(B+C)$ are synthesised concurrently during grain development and they can be seen as early as 10 DAA. Simultaneous synthesis of storage proteins has also been reported in durum wheat (Bénétrix et al. 1994). These measurements indicated a general increase in the absolute amounts of LMW and HMW glutenin subunits with the grain development until the end of the cell enlargement phase (about 35 DAA) for the two genotypes Soissons and Thésée (Fig. 6). Whereas the timing of accumulation of glutenin subunits in each of Soissons and Thésée was very similar, significant differences occurred in the total amount of HMWgs in mature kernels.

The quantity of HMWgs accumulated at maturity for the genotype Soissons is twice the quantity of Thésée even though the quantities of LMWgs for Thésée are slightly greater than the LMWgs of Soissons. The proportion of high molecular weight subunits increased slightly from about $17 \%$ to $21 \%$ and $35 \%$ to $43 \%$ of the whole glutenin for Thésée and Soissons respectively (Table 1).

The percentages of each HMW-gs in ground kernels are recorded in the same table. Remarkable qualitative shifts between high molecular weight glutenins were observed during ripening. For Soissons, the subunit $2^{*}$ dominated the RP-HPLC pattern in the first stage of the kernel development. Then, the percentage of this subunit decreased as well as those of subunits 10 and 8 (from $26 \%$ to $19 \%$, from $20 \%$ to $17 \%$ and from 16 to $12 \%$, respectively). The HMWgs 7 and 5 increased (from $21 \%$ to $27 \%$ and from 17 to 25 respectively) in the later stages.

For Thésée, the subunit 2 dominated at all stages during the ripening period and its percentage remained slightly stable with a very slow decrease after 30 DAA (from 44 to $41 \%$ ). While the percentage of subunit 8 as well as subunit 6 
increased during the last stages (from $16 \%$ to $24 \%$ and, from $7 \%$ to $14 \%$, respectively), the percentage of subunit 12 decreased form $30 \%$ to $24 \%$.

Accumulation of SDS-insoluble polymers under pre-mature desiccation

For Soissons and Thésée, we found that the period of most rapid formation of SDS-insoluble polymers coincided with the period of rapid water loss (after 32 DAA). It was then interesting to determine if the process of water loss from the grain may play a role in the formation of SDS-insoluble polymers. In order to understand this process well, we applied artificial desiccation on wheat kernels in the early stages of the grain development, from 20 DAA to 32 DAA, during the cell enlargement phase. Fig. 7 shows the accumulation of polymeric fraction in the kernels in relation to the early desiccation compared to controls.

The grain dehydration by ventilation at low temperature $\left(30^{\circ} \mathrm{C}\right)$ led for the two genotypes to an insolubilisation mechanism for a part of the accumulated polymers whatever the stage of development of the kernels (from 20 DAA to 32 DAA). These results are really close to the observations done in natural conditions during the grain desiccation phase (after 30-32 DAA, Fig. 4b).

The molecular size distribution of the polymers produced by artificial desiccation and estimated by the SDS-extractability criterion was not stable during grain development. Actually, the SDS-insoluble polymers/Total polymers ratio increased regularly between 20 DAA and 32 DAA from $13.1 \%$ to $27.1 \%$ and from $33 \%$ to 53\% for Thésée and Soissons, respectively (Figs. $7 a$ and $7 b$ ). The genotype Thésée possessed a SDS-insoluble polymer content always lower than Soissons' for the same physiological stage (for example, $25.2 \%$ versus $45 \%$ for Thésée and Soissons respectively at $28 \mathrm{DAA})$. 
At the end of the cell enlargement phase (after 32 DAA), corresponding to the end of the total protein accumulation, the polymer content obtained after dehydration is very close to the one obtained at maturity for the two genotypes. At the same time, the SDS-insoluble polymers/total polymers ratio measured at 32 DAA after dehydration is not significantly different from the mature ratio (53 DAA, with $27.1 \%$ versus $29.8 \%$ and $53 \%$ versus $48 \%$, respectively, for Thésée and Soissons).

\section{Discussion}

We have shown that, for these two varieties of wheat, there was a co-ordinated initiation of storage protein biosynthesis. Subsequent accumulation of different groups of storage proteins and polymer levels was progressive until seed maturity. The absolute amounts of the storage proteins thus increased during seed development. However, the accumulation rate varied between different groups of proteins, indicating differential regulation of protein biosynthesis. This could be considered at three levels.

The order of accumulation of protein was: albumins/globulins, monomers, polymeric proteins. Unlike monomers and polymeric proteins, the accumulation of albumins and globulins continued only until the early stages (during the cell division), confirming that these are metabolic or structural proteins. These observations were in total agreement with previous work (Jennings and Morton 1963; Flint et al. 1975; Stenram et al. 1990; Gupta et al. 1996; Stone and Nicolas 1996), who showed a reduction of the proportion of albumins/globulins in grain proteins during grain growth.

Second, the ratio of polymers/monomers was stable during the cell division and the cell enlargement stages (until 31 DAA) and then increased during the 
desiccation stage. Other workers have found that this ratio is stable (Kaczkowski et al. 1986), decreases towards maturity (Stenram et al. 1990) or varies throughout grain filling (Huebner et al. 1990). In the opinion of Stone and Nicolas (1996), some of these differences may be related mainly to the method of analysis for polymer estimation, which varied between authors.

Third, although the polymer accumulation was a continuous process commencing as early as 7 DAA, the accumulation of SDS-insoluble polymers began only during the late stages of the grain development. For both Soissons and Thésée, the period of most rapid accumulation of SDS-insoluble polymers coincided with the period of rapid water loss (after 32 DAA). These results are in close agreement with those of several workers (Bénétrix et al. 1994; Gupta et al. 1996; Stone and Nicolas 1996). Similarly, Woodman and Engledow (1924) found that the first signs of gluten formation corresponded with the commencement of grain desiccation. The question arises as to whether there is a relation between the SDS-insoluble polymers accumulation and the rapid water loss from the grains. The similarity in the timing of the events suggests this to be the case.

In order to verify this hypothesis, we applied artificial desiccations by ventilation at $30^{\circ} \mathrm{C}$ to grains during the cellular enlargement phase. The dehydration of kernels in development led to an increase of the polymer quantity and to the deposition of SDS-insoluble polymers for the two genotypes studied. These observations are in total agreement with the results obtained in natural conditions. Whatever the physiological stage of the grain during the cell enlargement phase (between 20 and 32 DAA), the massive loss of grain water results in the same phenomenon, that means an increase of the polymeric content with a deposition of the insoluble 
fraction. We can confirm that it is not necessary to reach a certain amount of total polymers accumulated to obtain the massive accumulation of the unextractable polymeric fraction since we can observe this insolubilisation at any time. These results contradict the hypothesis of Gupta et al. (1996) according to which the SDS-insoluble polymer formation would be induced only when a certain amount of total polymers was accumulated, i.e. $60-75 \%$.

For the two genotypes, the accumulation of the polymeric fractions coincides with the accumulation of the glutenin subunits (HMWgs and LMWgs) in the grains. Unlike other work (Seilmeier et al. 1990; Gupta et al. 1996), our results show a certain stability of the ratio HMWgs/LMWgs during the grain development. Actually, even if the percentage of the HMWgs increased during the latest phases, this increase was not very significant. The percentage of the HMWgs allows us to highly differentiate the two genotypes. Then, Soissons possesses twice as many HMWgs subunits as Thésée. Even if the two genotypes have the same amount in total polymers at maturity, the polymer distribution is highly correlated with the percentage of the HMWgs within the glutenins. These results, which show the quantitative importance of the HMWgs subunits for the SDS-insoluble polymer formation, are in total agreement with the observations made by Gupta and MacRitchie 1994 ; Gupta et al. 1995 ; Cornec 1994 from isogenic lines and translocations. Even when LMWgs subunits can polymerise alone (Gao and Bushuk 1993), a quantitative deficit in high molecular weight glutenin subunits reduces significantly the proportion in high mass polymers (SDS-insoluble polymers). However, in our study, even if the quantitative differences in HMWgs can explain by themselves the variation of the polymer distribution between 
Soissons and Thésée, we must not forget the effects due to the allelic variations coded by the Glu-1D locus. Actually, the presence of the 5 and $10 \mathrm{HMW}$ subunits from Soissons increases the polymeric nature of the glutenins by opposition to the 2 and 12 subunits from Thésée (Gupta et al. 1994 ; Gupta and MacRitchie 1994 ; Popineau et al. 1994b).

At maturity, the HMWg percentage in the glutenins and the allelic composition of those HMWgs demonstrate a great importance for the definition of the technological properties modifying significantly the grain polymer distribution.

From our results, it appears that the polymeric distribution obtained at maturity does not result from a unique and continuous mechanism. During the kernel development (cell division and cell enlargment), glutenin polymers (association of monomers by covalent interactions with disulfide bond formation) appear by a slow mechanism. In fact, the work of Rubin et al. (1992), Shani et al. (1993), Shewry et al. (1995) and Galili et al. (1996) suggest that the HMWgs and certainly the LMWgs would associate for a part or in totality in the rough endoplasmic reticulum. This mechanism of polymerisation would continue in the protein bodies after the time necessary to their formation (Figs. $5 a$ and $5 b$ ). It is then possible to consider that the HMWgs and LMWgs were stocked into the dense protein bodies under polymers of small mass and that, during this storage, these proteins linked by disulfide bonds to give more complex structures.

During the desiccation phase of the kernel that coincides with the breakdown of the protein bodies (Pernollet and Camilleri 1983), the massive loss of water induces the insolubilisation of a part of the polymeric material previously accumulated. Even if we don't exclude the possibility that the process of water 
loss from the grain may play a role in enhancing disulfide bonding and the creation of SDS-insoluble polymers, another explanation for the late occurrence of glutenin polymer insolubility, might be greatly enhanced by secondary interactions occuring during compression of protein bodies at the end of development. In this hypothesis, the loss of water from the kernel promotes the aggregation of the polymeric structures by facilitating in particular the interactions between the repetitive domains (intermolecular $\beta$-sheets) of the glutenin subunits (Pezolet et al. 1992 ; Popineau et al. 1994a). Then, as shown by our results, the aggregation level would obtained would thus be highly influenced by the polymerisation level reached during grain development. 


\section{References}

Bénétrix, F., Kaan. F., and Autran, J.-C. (1994). Changes in protein complexes of durum wheat in developping seed. Crop Science 34, 462-468.

Bietz, J.A., and Huebner, F.R. (1980). Structure of glutenin : Achievements at the northern regional research centre. Annals of Technology and Agriculture 29, 249277.

Chanda, S.V., and Singh, Y.D. (1996). Biochemical analysis of developing wheat grains. Journal of Agronomy and Crop Science 176, 131-139.

Cornec, M. (1994). Comportement rhéologique du gluten: influence de la composition en prolamines et leur état d'association. Thèse de Doctorat, Université de Nantes, 220 p.

Dachkevitch, T., and Autran, J.-C. (1989). Prediction of baking quality of bread wheats in breeding programs by size-exclusion high-performance liquid chromatography. Cereal Chemistry 66, 448-456.

Dell'Aquila, A., Colaprico, G., Taranto, G., and Carella, G. (1983). Endosperm changes in developing and germinating T. aestivum, T. turgidum and T. monococcum seeds. Cereal Research Communications 11, 107-113.

Field, J.M., Shewry, P.R., and Miflin, B.J. (1983). Solubilisation and characterisation of wheat gluten proteins : Correlations between the amount of aggregated proteins and baking quality. Journal of the Science of Food and Agriculture 34, 370-377.

Flint, D., Ayers, G.S., and Ries, S.K. (1975). Synthesis of endosperm proteins in wheat seed during maturation. Plant Physiology 56, 381-384.

Fu, B.X., and Sapirstein, H.D. (1996). Procedure for isolating monomeric proteins and polymeric glutenin of wheat flour. Cereal Chemistry 73,143-152. 
Galili., G., Shimoni, Y., Giorini-Silfen, S., Levanony, H., Altschuler, Y., and Shani, N. (1996). Wheat storage proteins : Assembly, transport and deposition in protein bodies. Plant Physiology and Biochemistry 34, 245-252.

Gao, L., and Bushuk, W. (1993). Polymeric glutenin of wheat lines with varying number of high molecular weight glutenin subunits. Cereal Chemistry 70, 475-480. Green, C.F., Dawkins, T.C.K., and McDonald, H.G. (1985). Influence of chlorocholine chloride on grain growth of winter barley (Hordeum distichon L. Cv. Igril) in the field. Journal of Experimental Botany 36, 1126-1133.

Gupta, R.B., Batey, I.L., and MacRitchie, F. (1992). Relationship between protein composition and functional properties of wheat flours. Cereal Chemistry $69,125-131$.

Gupta, R.B., Khan, K., and MacRitchie, F. (1993). Biochemical basis of flour properties in bread wheats. I. Effects of variation in the quality and size distribution of polymeric protein. Journal of Cereal Science 18, 23-41.

Gupta, R.B., Paul, J.G., Cornish, G.B., Palmer, G.A., Bekes, F., and Rathjen, A.J. (1994). Allelic variation at glutenin subunit and gliadin loci, Glu-1, Glu-3 and Gli-1 of common wheats. I. Its additive and interaction effects on dough properties. Journal of Cereal Science 19, 9-17.

Gupta, R.B., and MacRitchie, F. (1994). Allelic variation at glutenin subunit and gliadin loci, Glu-1, Glu-3 and Gli-1 of common wheats. II. Biochemical basis of the allelic effects on dough properties. Journal of Cereal Science 19, 19-29.

Gupta, R.B., Popineau, Y., Lefebvre, J., Cornec, M., Lawrence, G.J., and MacRitchie, F. (1995). Biochemical basis of flour properties in bread wheats. II. Changes in polymeric protein formation and dough/gluten properties associated 
with the loss of low $M_{r}$ or high $M_{r}$ glutenin subunits. Journal of Cereal Science 21, 318-331.

Gupta, R.B., Masci, S., Lafiandra, D., Bariana, H.S., and MacRitchie, F. (1996). Accumulation of protein subunits and their polymers in developing grains of hexaploid wheats. Journal of Experimental Botany 47, 1377-1385.

Huebner, F.R., and Wall, J.S. (1976). Fractionation and quantitative differences of glutenin from wheat varieties varying in baking quality. Cereal Chemistry 53, 258-269.

Huebner, F.R., Kaczkowski, J., and Bietz, J.A. (1990). Quantitative variation of wheat proteins from grain at different stages of maturity and from different spike locations. Cereal Chemistry 67, 464-470.

Jennings, A.C., and Morton, R.K (1963). Changes in carbohydrate, protein and non-protein nitrogenous compounds of developing wheat grains. Australian Journal of Biological Sciences 16, 318-331.

Jia, Y.Q., Masbou, V., Aussenac, T., Fabre, J.-L., and Debaeke, P. (1995). Effects of nitrogen fertilization and maturation conditions on protein aggregates and on the breadmaking quality of Soissons, a common wheat cultivar. Cereal Chemistry 73, 123-130.

Jia, Y.Q., Fabre, J.-L., and Aussenac, T. (1996). Effects of growing location on response of protein polymerization to increased nitrogen fertilization for the common wheat cultivar Soissons: Relationship with some aspects of the breadmaking quality. Cereal Chemistry 73, 526-532.

Johansson, E., Oscarson, P., Heneen, W.K., and Lundborg, T. (1994). Differences in accumulation of storage proteins between wheat cultivars during development. Journal of the Science of Food and Agriculture 64, 305-313. 
Kaczkowski, J., Kos, S., and Moskal, M. (1986). Protein fractional composition in developing wheat grains. Die Nahrung 30, 437-439.

Khan, K., and Huckle, L. (1992). Use of multistacking gels in sodium dodecyl sulfate-polyacrylamide gel electrophoresis to reveal polydispersity, aggregation, and disaggregation of the glutenin protein fraction. Cereal Chemistry 69, 686-688. Kurowska, E., and Bushuk, W. (1988). Solubility of flour and gluten protein in a solvent of acetic acid, urea, and cetyltrimethylammonium bromide, and its relationship to dough strength. Cereal Chemistry 65, 156-158.

Marchylo, B.A., Hatcher, D.W. and Kruger, J.E. (1989). Identification of wheat cultivars by reversed-phase high-performance liquid chromatography of storage proteins. Cereal Chemistry 65, 28-40.

Pernollet, J.C., and Camilleri, C. (1983). Formation and development of protein bodies in the wheat endosperm. Physiologie Végétale 21, 1093-1103.

Pezolet, M., Bonenfant, S., Dousseau, F., and Popineau, Y. (1992). Conformation of wheat gluten proteins. Comparison between functional and solution states as determined by infra-red spectroscopy. FEBS Letters. 299, 247250.

Popineau, Y., Bonenfant, S., Cornec, M., and Pezolet, M. (1994a). A study by infrared spectroscopy of the conformations of gluten proteins differing in their gliadin and glutenin compositions. Journal of Cereal Science 20, 15-22.

Popineau, Y., Cornec, M., Lefebvre, J., and Marchylo, B. (1994b). Influence of High $M_{r}$ glutenin subunits on glutenin polymers and rheological properties of glutens and gluten subfractions of near-isogenic lines of wheat Sicco. Journal of Cereal Science 19, 231-241. 
Rubin, R., Levanony, H., and Galili, G. (1992). Evidence for the presence of two different types of protein bodies in wheat endosperm. Plant Physiology 99, 718724.

Seilmeier, W., Wieser, H., and Belitz, H.D. (1990). Weizen während der reifung. Analyse der gliadine und glutenine mittels RP-HPLC. Zeitschrift für LebensmittelUntersuchung und-Forschung 191, 99-103.

Shani , N., Rosenberg, N., Kasarda, D.., and Galili, G. (1993). Mechanisms of assembly of wheat high molecular weight glutenins inferred from expression of wild-type and mutant subunits in transgenic tobacco. The Journal of Biological Chemistry 12, 8924-8930.

Shewry, P.R., and Tatham, A.S. (1990). Review article. The prolamin storage proteins of cereal seeds : structure and evolution. Biochemical Journal 167, 1-12.

Shewry, P.R., Sayanova, O., Tatham, A.S., Tamas, L., Turner, M., Richard, G., Hickman, D., Fido, R., Halford, N.G., Greenfield, J., Grimwade, B., Thomson, N., Miles, M., Freedman, R., and Napier, J. (1995). Structure, assembly and targeting of wheat storage proteins. Journal of Plant Physiology 145, 620-625.

Singh, N.K., Donovan, R., and MacRitchie, F. (1990a). Use of sonication and size-exclusion high-performance liquid chromatography in the study of wheat flour proteins. I. Relative quantity of glutenin as a measure of breadmaking quality. Cereal Chemistry 67, 161-170.

Singh, N.K., Donovan, R., and MacRitchie, F. (1990b). Use of sonication and size-exclusion high-performance liquid chromatography in the study of wheat flour proteins. II. Dissolution of total proteins in the absence of reducing agents. Cereal Chemistry 67,150-161. 
Stenram, U., Heneen, W.K., and Oleredd, R. (1990). The effect of nitrogen fertilizers on protein accumulation in wheat (Triticum aestivum L.). Swedish Journal of Agricultural Research 20, 105-114.

Stone, P.J., and Nicolas, M.E. (1996). Varietal differences in mature protein composition of wheat resulted from different rates of polymer accumulation during grain filling. Australian Journal of Plant Physiology 23, 727-737.

Wall, J.S. (1979). The role of wheat proteins in determining baking quality. In : 'Recent advances in the biochemistry of cereals'. (Eds D.L. Laidman and R.G. Wyn Jones.) pp. 275-312. (Academic Press: London, UK.).

Wang, Y.P., and Gifford, R.M. (1995). A model of wheat grain growth and its applications to different temperature and carbondioxide levels. Australian Journal of Plant Physiology 22, 843-855.

Woodman, H.E., and Engledow, F.I. (1924). A chemical study of the development of the wheat grains. Journal of Agricultural Science 14, 563-586. 


\section{CAPTIONS}

Fig. 1. Grain filling period of Soissons and Thésée genotypes. (a) Evolution of dry matter per kernel as a function of the days after anthesis (DAA). (b) Evolution of water quantity per kernel as a function of the DAA. $\square$ Thésée, $O$ Soissons. Stages : P1, cell division ; P2, cell enlargement ; and P3, dehydration and grain maturation. The vertical bars represent the standard deviation $(n=3)$.

Fig. 2. Evolution of the quantity of the different protein fractions (in arbitrary units per kernel) for (a) Soissons and (b) Thésée, as a function of the days after anthesis. $\square$ insoluble polymers ; O soluble polymers ; $\square$ albumins and globulins ; $\Delta$ monomers ; and $\square$ total proteins. Stages: P1, cell division ; P2 cell enlargement ; and P3, dehydration and grain maturation.

Fig. 3. Evolution of (a) the Polymer/Monomer ratio (\%) and (b) quantity of monomers and total polymers in arbitrary units as a function of the days after anthesis. (a) $\bigcirc$ Soissons, and $\bullet$ Thésée. (b) $\square$ Monomers, and $\bigcirc$ total polymers of Thésée ; Monomers, and $\bullet$ total polymers of Soissons. The stages are identical to those described in Fig. 1.

Fig. 4. Accumulation of total polymers, SDS-soluble and SDS-insoluble polymers and evolution of the percentage of SDS-insoluble polymers in total polymers as a function of the days after anthesis. (a) total polymers per kernel for - Soissons, and $\bigcirc$ Thésée. (b) open symbols are for Thésée and closed symbols are for Soissons. $\triangle$ SDS-soluble polymers, and O SDS-insoluble polymers. (c) SDS insoluble polymers as a proportion of total polymer (\%). - Soissons, and $\bigcirc$ Thésée. 
Fig. 5. SDS-PAGE using multistacking gels of non-reduced soluble protein extracts of Soissons (a) and Thésée (b) kernels during the grain ripening (from 13 to 53 DAA). The regions of the monomers and the polymers are indicated. The percentage of acrylamide is presented to the left of the gel. $\mathrm{Sd}=$ molecular weight standards.

Fig. 7. Evolution of the high (HMW) and low molecular weight (LMW) glutenin subunits per kernel as a function of the days after anthesis. O HMWgs of Thésée ; - HMWgs of Soissons ; प LMWgs of Soissons, and $\Delta$ LMWgs of Thésée.

Fig. 8. Quantity of unextractable polymers as a function of treatment (control (C) and desiccated (D)) and days after anthesis (20 DAA, 24 DAA, 28 DAA, 32 DAA and mature stage 53 DAA) for the two genotypes Soissons (a), and Thésée (b). $\square$ unextractable polymers of control, and $\square$ unextractable polymers of desiccated. The numbers on the bars represent the ratio SDS-unextractable polymers to total polymers in percent. 
Australian Journal of Plant Physiology Carceller and Aussenac

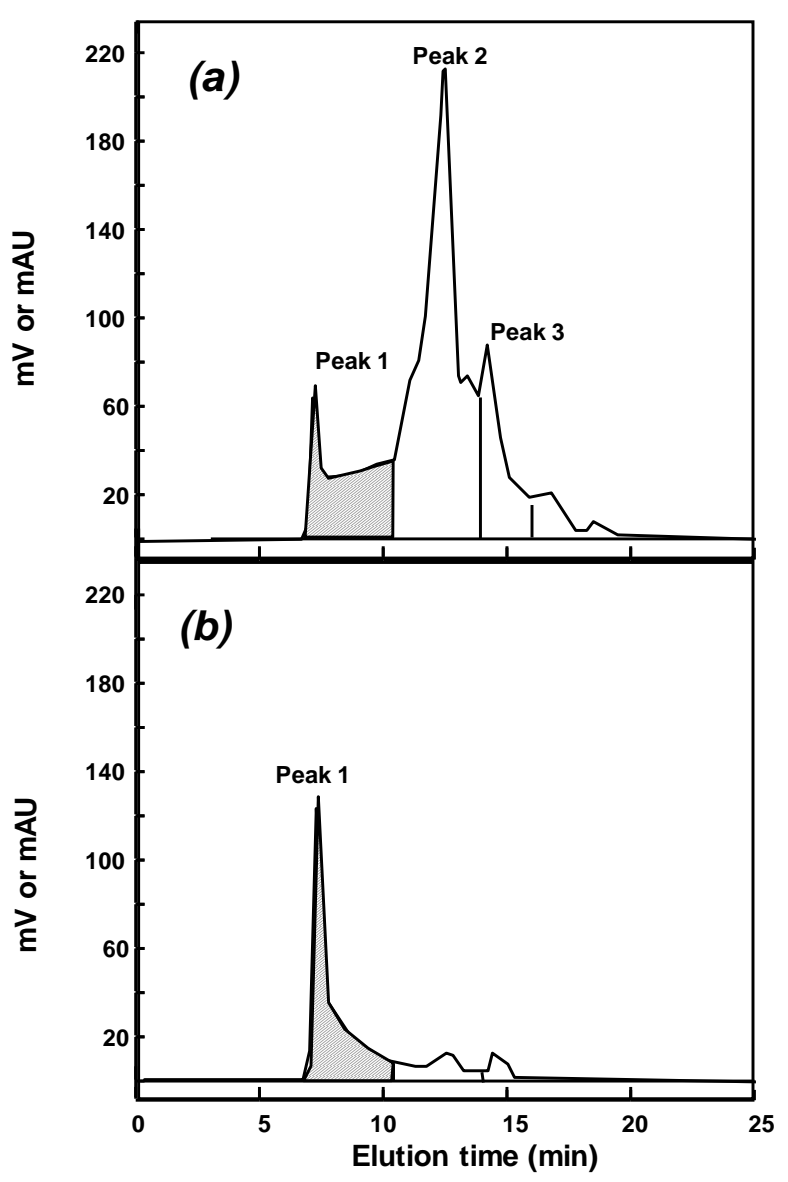

28

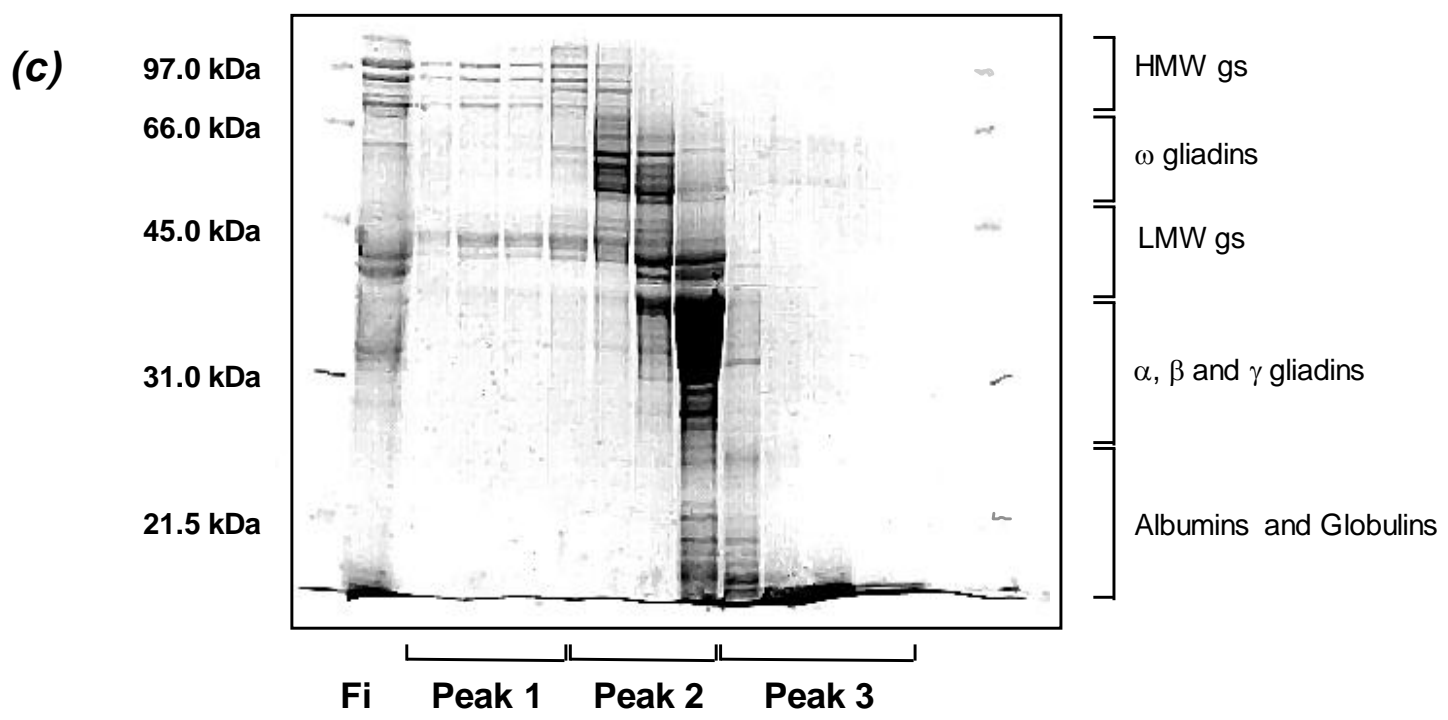

Figures $1 \mathrm{a}, \mathrm{b}$ and $\mathrm{c}$ 


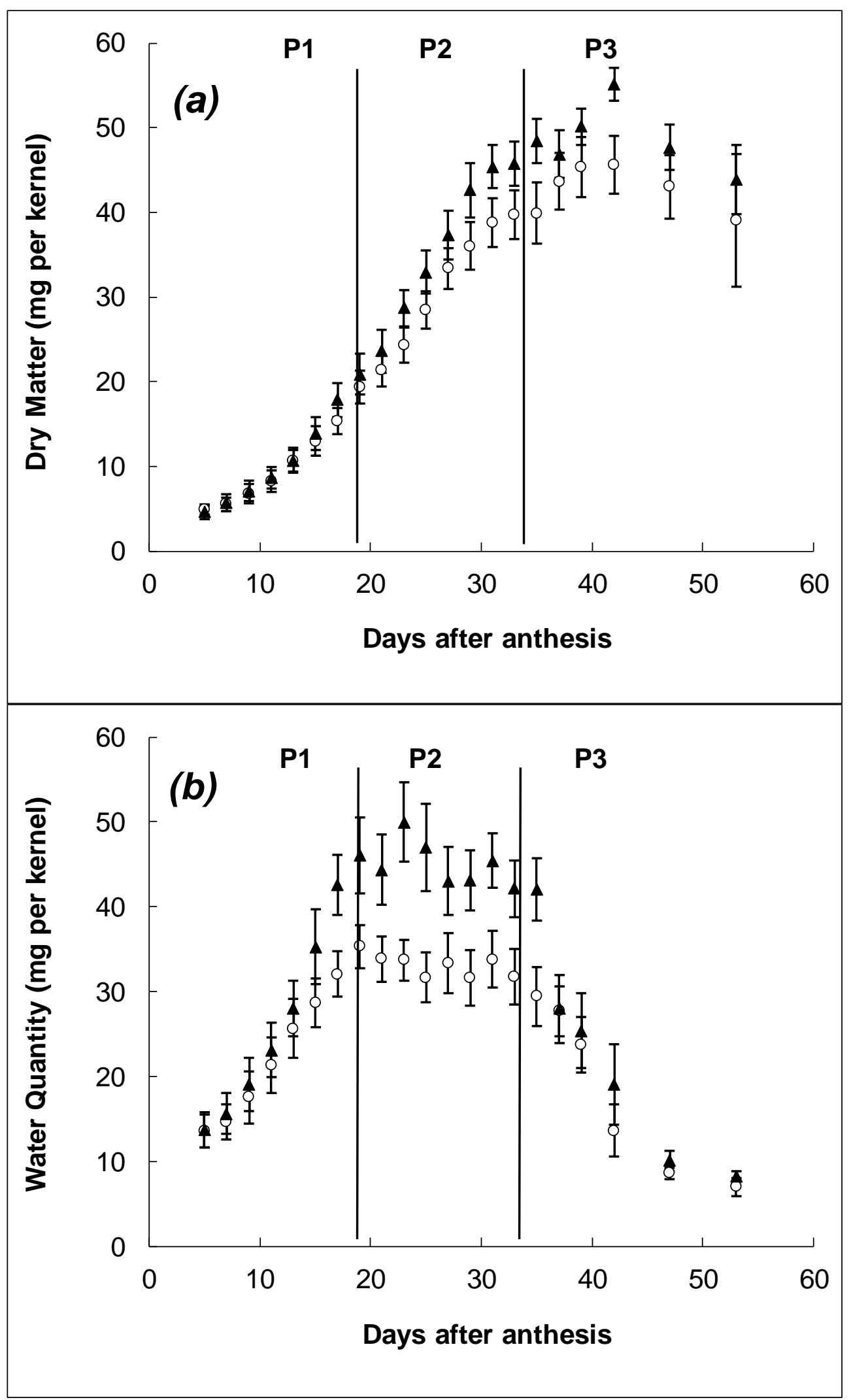




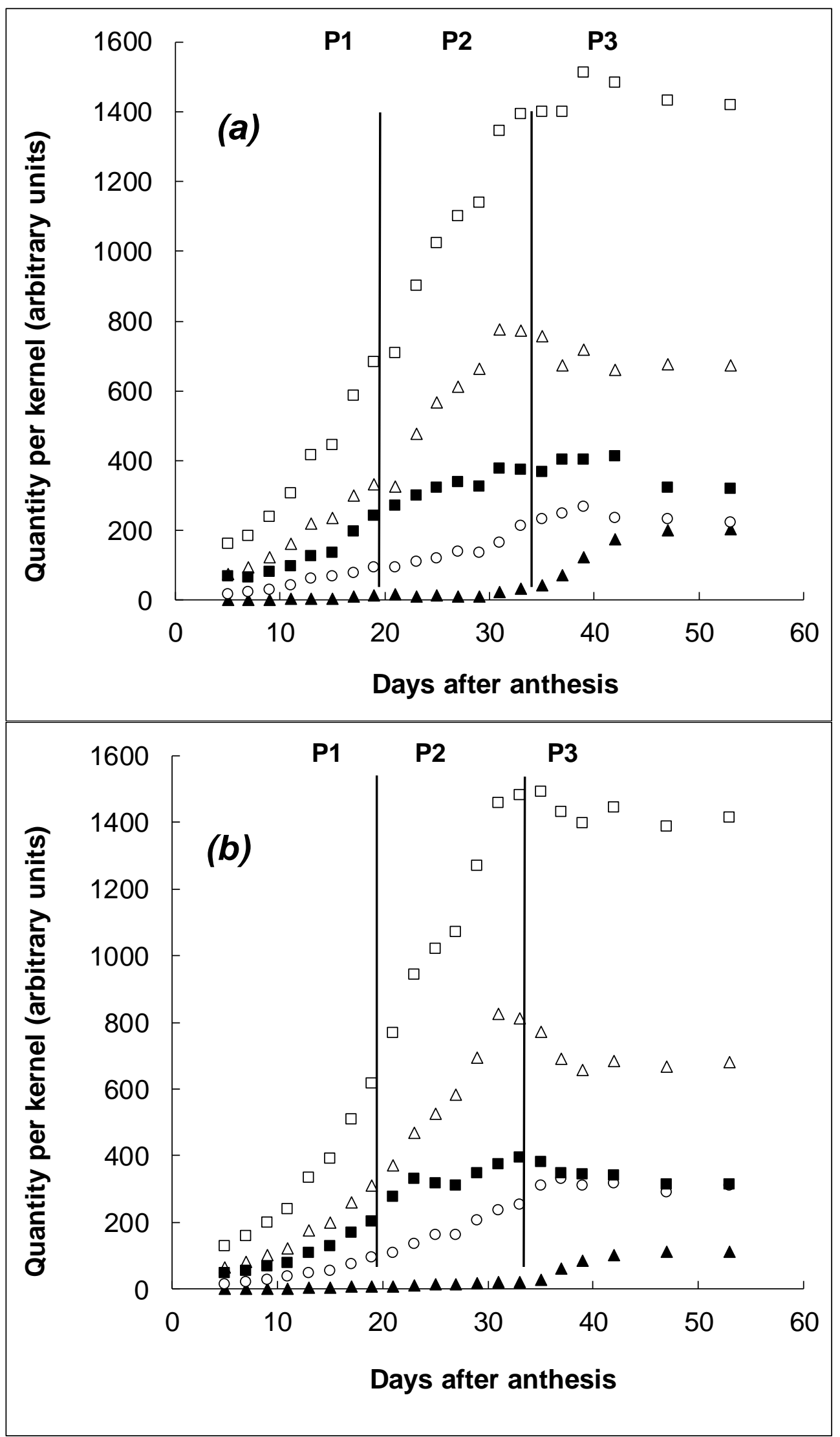



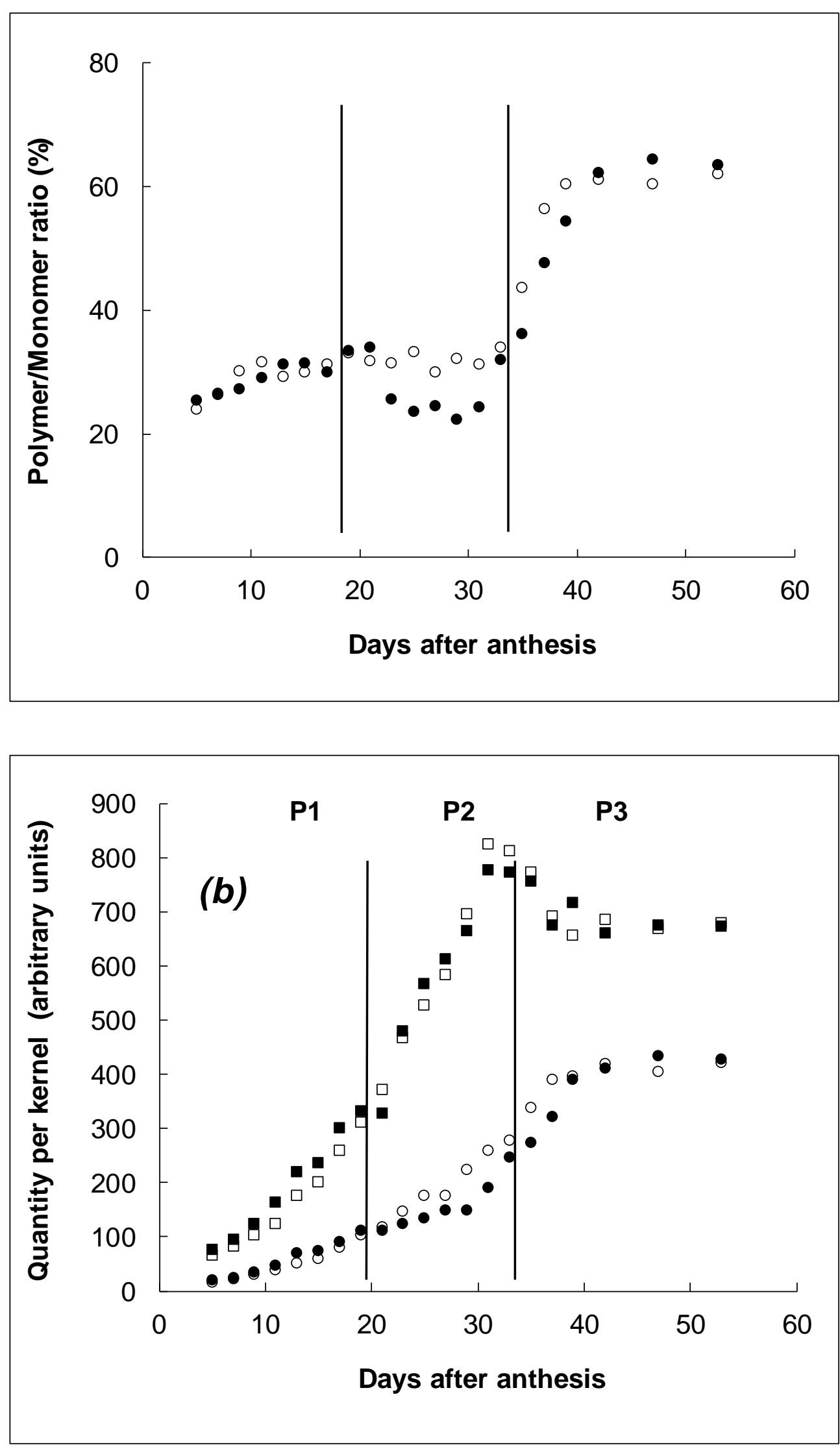

Figures $4 a$ and $b$ 

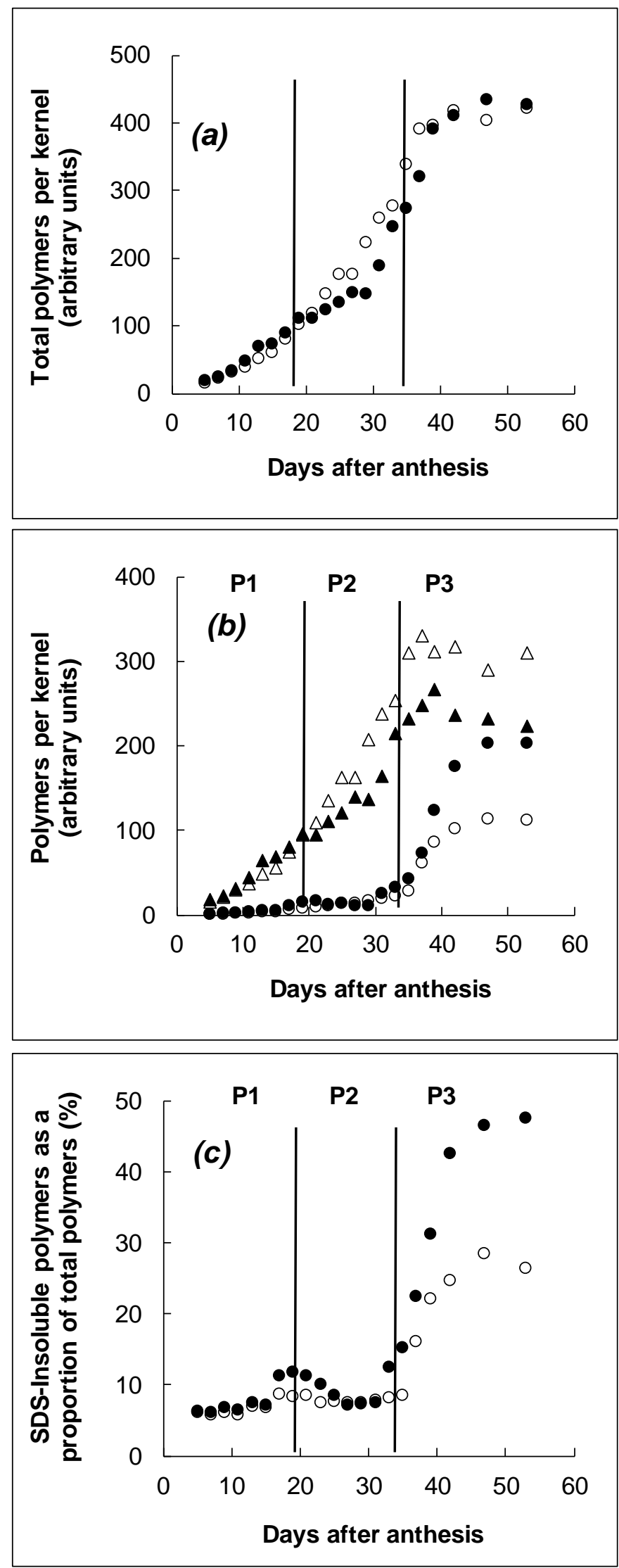

Figures $5 \mathrm{a}, \mathrm{b}$ and $\mathrm{c}$ 
(a)
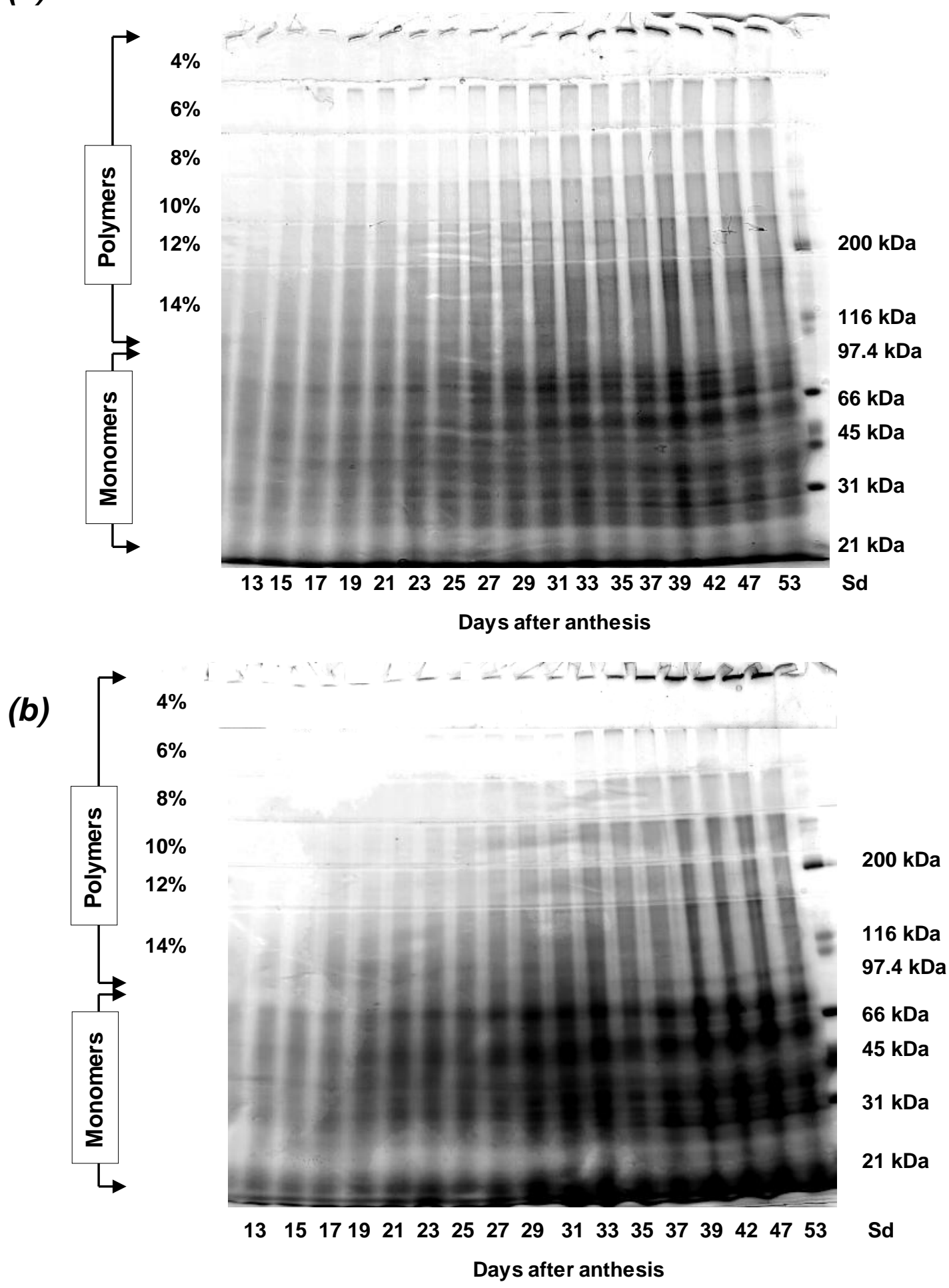

Figures $6 a$ and $b$ 


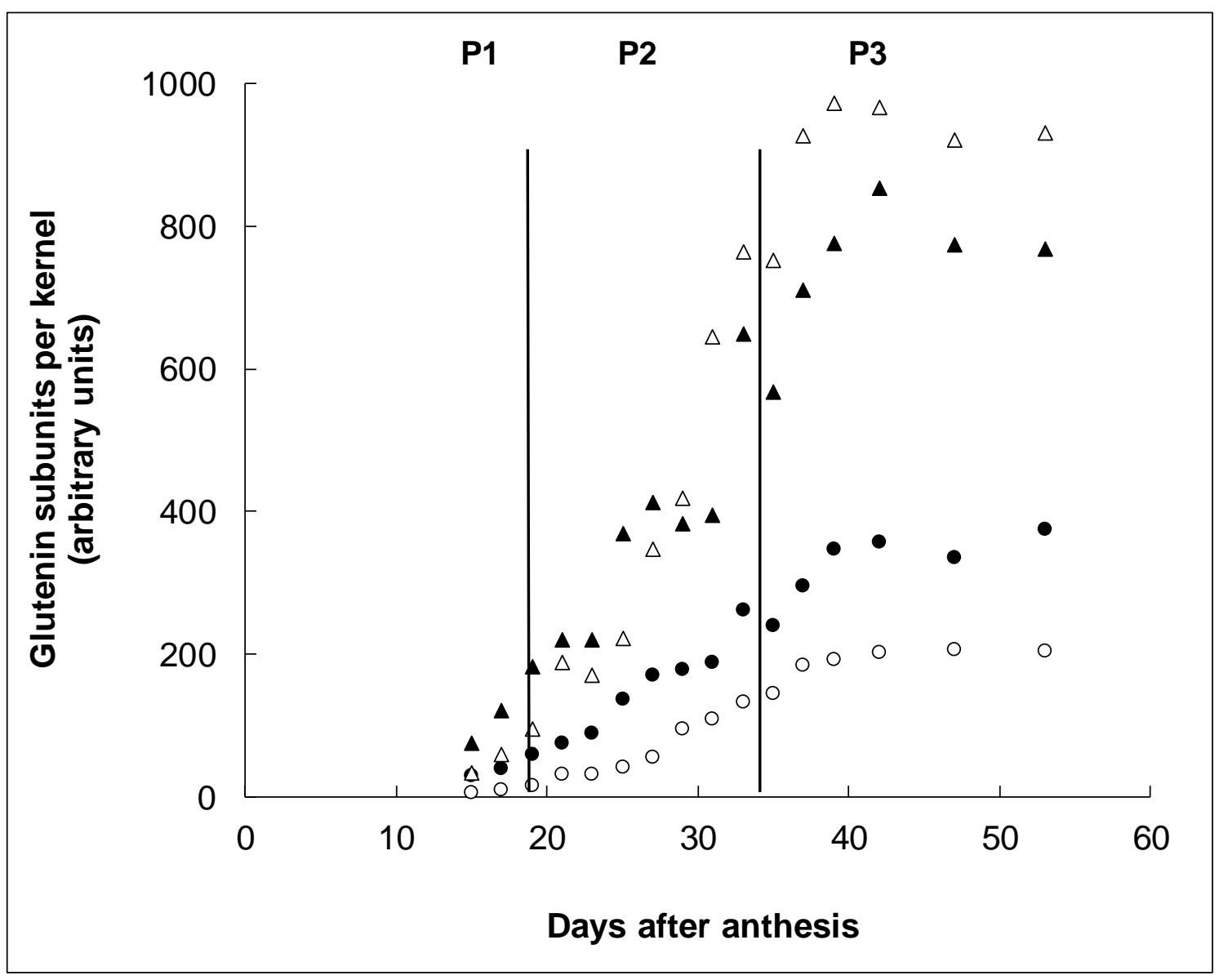

Figure 7 


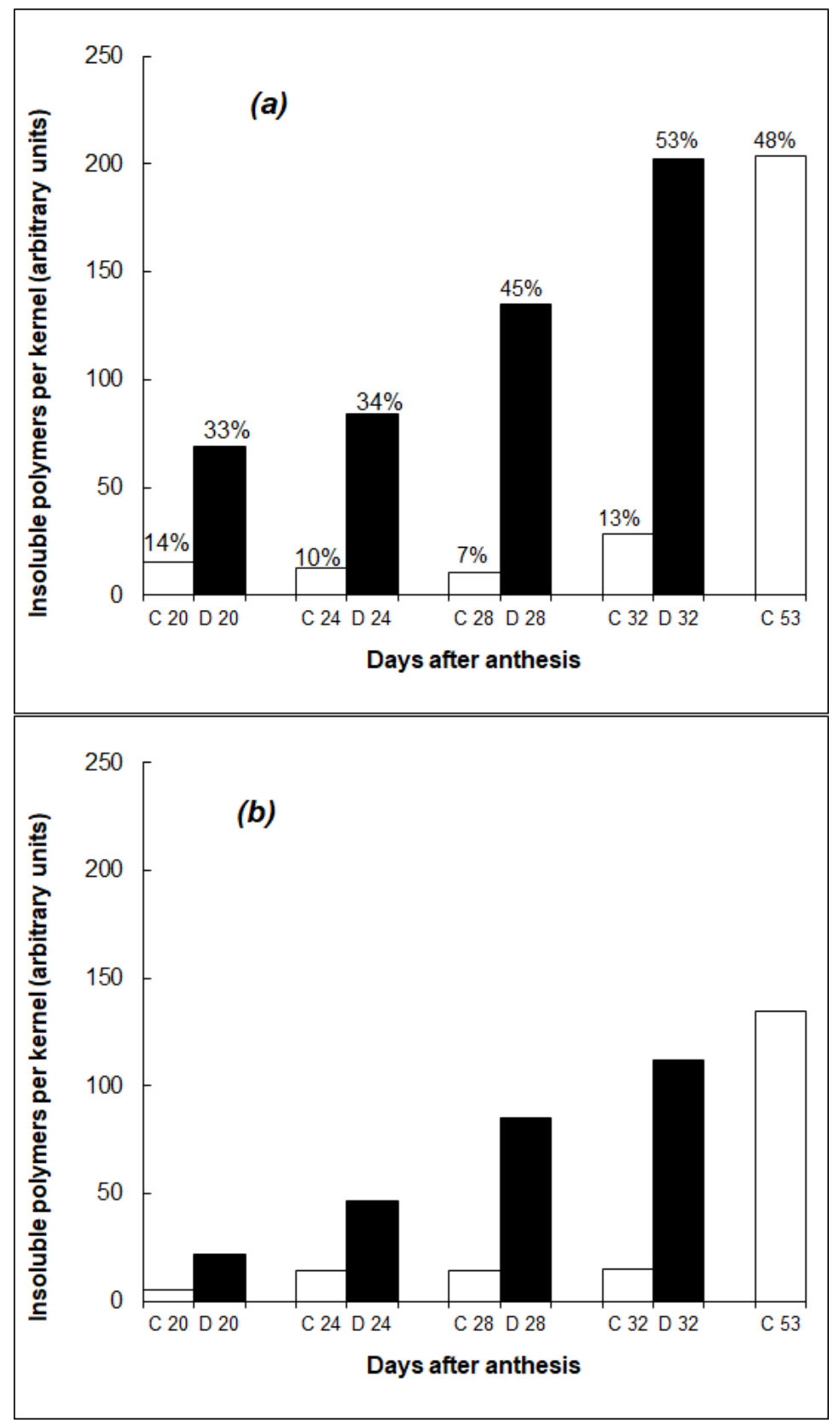

Figures 8 a and $b$ 